\title{
HYDROLYSIS OF VARIOUS THAI AGRICULTURAL BIOMASSES USING THE CRUDE ENZYME FROM ASPERGILLUS ACULEATUS IIZUKA FR60 ISOLATED FROM SOIL
}

\author{
Atcha Boonmee* \\ Department of Microbiology, Faculty of Science, Khon Kaen University, Thailand.
}

Submitted: December 17, 2010; Approved: January 16, 2012.

\begin{abstract}
In this study, forty-two fungi from soil were isolated and tested for their carboxymethyl cellulase (CMCase) and xylanase activities. From all isolates, the fungal isolate FR60, which was identified as Aspergillus aculeatus Iizuka, showed high activities in both CMCase and xylanase with $517 \mathrm{mU} / \mathrm{mg}$ protein and 550 $\mathrm{mU} / \mathrm{mg}$ protein, respectively. The crude enzyme from A. aculeatus Iizuka FR60 could hydrolyze several agricultural residues such as corncob, and sweet sorghum leaf and stalk at comparable rates with respect to the tested commercial enzymes and with a maximum rate in rice hull hydrolysis ( $29 \mu \mathrm{g}$ sugar $\mathrm{g}^{-1}$ dry weight substrate $\mathrm{mg}^{-1}$ enzyme $\mathrm{hr}^{-1}$ ). The highest amount of glucose was obtained from corncob by using the crude enzyme from A. aculeatus Iizuka FR60 (10.1 g/100 g dry substrate). From overall enzymatic treatment results, the lowest sugar yield was from rice hulls treatment (1.6 g/100 g dry weight) and the highest amount of reducing sugar was obtained from rice straw treatment $(15.3 \mathrm{~g} / 100 \mathrm{~g}$ dry weight). Among tested agricultural wastes, rice hull could not be effectively hydrolyzed by enzymes, whereas sugarcane leaf and stalk, and peanut shell could be effectively hydrolyzed (30-31\% total sugar comparing with total sugar yield from acid treatment).
\end{abstract}

Key words: Agricultural wastes, Aspergillus aculeatus Iizuka, Enzymatic hydrolysis, Mean specific rate, Reducing sugars

\section{INTRODUCTION}

Due to global warming problems and continuously decreasing of fossil fuel sources, the demand for alternative energy resource such as gasohol and biodiesel has increased significantly. Used in gasoline as a fuel oxygenate in highoctane fuels instead of methyl tertbutyl ether (MTBE), ethanol demand has increased substantially since MTBE can cause a groundwater pollutant and a possible carcinogen (16). Currently, most fuel ethanol in Thailand is produced from sugar cane, molasses, and cassava (2). The biomass feedstock represents about $40 \%$ of the bioethanol production costs (11). Therefore, reducing the cost of ethanol production by using lignocellulosic materials such as bagasse, corncob, or rice straw as an alternative feedstock has received much attention from researchers nowadays. The choice of the best technology 
for the conversion of lignocelluloses to bioethanol should be decided based on overall economics (lowest cost), environment (lowest pollutants), and energy (higher efficiencies) (11). Therefore, comprehensive process development and optimization are still required to make the process economically viable (8).

About 100 million metric tons of agricultural wastes are produced in Thailand per year (2) and could be considered for bioconversion. These lignocellulosic residues are available on a renewable basis as they are generated by the harvest and processing of sugar cane, rice, peanut, maize and sorghum, which are regularly cultivated crops. Various fermentable sugars such as glucose, xylose in hydrolysates of those agricultural wastes can be fermented to produce ethanol.

Although lignocellulosic residues provide inexpensive raw materials, cost intensive hydrolysis processes are required to obtain fermentable sugar. Hydrolysis of cellulose with diluted acid occurs at high-temperature, whereas hydrolysis with either concentrated acid or enzymes is performed at low-temperature $(10,32)$. A drawback of the acid hydrolysis is the formation of byproducts, which can negatively affect the fermentability of the hydrolysates $(25,27)$. The use of microbial enzymes for the hydrolysis of lignocellulosic materials is therefore widely researched because the hydrolysis products do not harm microorganisms used in fermentation processes. Since cellulose is the main component of plant biomass, most investigations of enzymic degradation of lignocellulosic materials have focused on cellulases. Numerous microorganisms can produce cellulases, among which fungi are the most potential cellulase producers. Most commercial cellulases are produced from fungi, especially Trichoderma species.

Extensive studies have been done concerning hydrolysis of various lignocellulosic materials including pretreatment strategies, dilute-acid hydrolysis, and enzymatic hydrolysis by commercial enzymes, however, only few types of lignocellulosic materials had been investigated $(5,6,14,18$,
$24,30,36)$. In this study, screening of lignocellulose-degrading fungi considering their cellulase and xylanase activities was investigated. Furthermore, the ability of a crude enzyme from the selected fungal isolate in hydrolyzing seven different Thai agricultural and agro-industrial materials comparing with acid hydrolysis and commercial enzymes was determined for its potential use as agricultural waste degrading agents.

\section{MATERIALS AND METHODS}

\section{Isolation of fungal strains}

Microbes were isolated from soil in the campus of Khon Kaen University, Thailand. The soil suspension was diluted $10^{-}$ 3 to $10^{-6}$ times. Each diluted suspension $(0.1 \mathrm{ml})$ was transferred by the spread plate method with a sterile glass spreader on petri plates containing rice straw agar $(2 \%(\mathrm{w} / \mathrm{v})$ blended and pretreated rice straw, $0.5 \%(\mathrm{w} / \mathrm{v}) \mathrm{K}_{2} \mathrm{HPO}_{4}, 0.1 \%$ (w/v) $\mathrm{NaCl}, 0.02 \%(\mathrm{w} / \mathrm{v}) \mathrm{MgSO}_{4} \cdot 7 \mathrm{H}_{2} \mathrm{O}$, and $0.06 \%(\mathrm{w} / \mathrm{v})$ $(\mathrm{NH} 4)_{2} \mathrm{SO}_{4}$ ). The petri plates were incubated at $30^{\circ} \mathrm{C}$ for $3-5$ days. Based on the growth on the rice straw agar plate, carboxymethyl cellulase (CMCase) and xylanase activities of each fungal isolate were carried out. The isolate FR60 was used for further studies. The young colonies of the fungal cultures were aseptically picked and transferred to $2 \%$ rice straw agar slants. These slants were incubated at $30^{\circ} \mathrm{C}$ for 4 days, and after a sufficient growth, they were stored at $4{ }^{\circ} \mathrm{C}$ in the refrigerator.

\section{Fungal characterization}

The fungal isolate FR60 was sent to National Center for Genetic Engineering and Biotechnology, Thailand (BIOTEC) and was identified based on of the morphological characteristics and certain standard confirmatory tests $(12,29)$.

\section{Crude enzyme preparation}

Fungal isolates were initially grown on $2 \%$ rice straw agar at $30^{\circ} \mathrm{C}$ for 5 days. The spore suspension of approximately $6 \times 10^{6}$ spores $\mathrm{ml}^{-1}$ was prepared in sterile water containing 
$0.05 \%(\mathrm{v} / \mathrm{v})$ Tween 80 . Thirty milliliters of $2 \%$ rice straw medium were inoculated with $0.4 \mathrm{ml}$ spore suspension in a 250 $\mathrm{ml}$ Erlenmayer flask. The culture was incubated for 5 days at $30^{\circ} \mathrm{C}$ and $150 \mathrm{rpm}$. After cultivation, the culture was centrifuged at $5,000 \mathrm{rpm}$ and $4^{\circ} \mathrm{C}$ for 10 minutes. The supernatant was carefully collected.

\section{CMCase and xylanase assays}

CMCase and xylanase activities were determined by the spectrophotometric method described by Miller et al. (21). A reaction mixture contains enzyme extract, carboxymethyl cellulose (CMC) or xylan (from oat spelts, Sigma) as a substrate, and dinitrosalicylic acid (DNS) as a coupling reagent. Crude enzyme and substrate were incubated at 30 and $50{ }^{\circ} \mathrm{C}$ for $30 \mathrm{~min}$. A similar reaction mixture was prepared for the control (the supernatant of the rice straw medium). Glucose or xylose was used as the standard for the estimation of reducing sugar. One unit of CMCase or xylanase activities is defined as the amount of enzyme that releases one micromole of reducing sugar per minute per milligram total protein in crude enzyme under the assay conditions. The enzyme activity is expressed as milliunit per milligram protein $(\mathrm{mU} / \mathrm{mg})$.

\section{Preparation of agricultural wastes as substrates for the hydrolysis}

Different agro-industrial residual substrates were identified and collected from the Faculty of Agriculture, Khon Kaen University, Thailand. They were chopped into $5 \mathrm{~cm}$ long pieces, and oven-dried at $105^{\circ} \mathrm{C}$ for 3 hours to reduce the moisture content. They were subsequently processed by using a USA standard sieve number 18 to obtain the mean particle size of 1.4-1.0 mm. The ground-powdered substrates were soaked in $15 \%(\mathrm{v} / \mathrm{v}) \mathrm{NH}_{4} \mathrm{OH}$ solution at a ratio of $1: 30(\mathrm{w} / \mathrm{v})$, and stirred on a magnetic stirrer at room temperature for 24 hours in order to delignify. The pretreated substrates were filtered with muslin cloth and the residue was neutralized with $1 \mathrm{M}$ $\mathrm{HCl}$, and washed 3 times with distilled water. This was then oven-dried at $90^{\circ} \mathrm{C}$ for 30 minutes, and stored until further use.

\section{Acid hydrolysis of the substrates}

The substrates were mixed with $0.5 \%(\mathrm{v} / \mathrm{v}) \mathrm{HCl}$ at a ratio of $1: 20(\mathrm{w} / \mathrm{v})$, and incubated at $120^{\circ} \mathrm{C}$ for 3 hours. After that, the mixture was filtered, the supernatant was kept, and the filtrate was further mixed with $5 \%(\mathrm{v} / \mathrm{v}) \mathrm{H}_{2} \mathrm{SO}_{4}$ at a ratio of $1: 30(\mathrm{w} / \mathrm{v})$ and incubated at $140^{\circ} \mathrm{C}$ for 3 hours. The supernatant of both hydrolysates were combined and used in the reducing sugar assay. Reducing sugars in the hydrolysates were estimated using the DNS method (20). The amount of glucose and xylose were determined by using High Performance Liquid Chromatography (HPL no.1-Shimadzu, Japan) under following conditions: Inertsil ${ }^{\circledR}$ HPLC column NH2 $5 \mu \mathrm{m} \mathrm{4.6 \times 250} \mathrm{mm;}$ mobile phase/liquid phase $65 \%$ acetonitrile (acetonitrile: $\mathrm{H}_{2} \mathrm{O}$ ); temperature $40^{\circ} \mathrm{C}$; flow rate $1 \mathrm{ml} / \mathrm{min}$; pressure $44 \mathrm{~kg} / \mathrm{cm}^{3}$; $\mathrm{p}_{\max }$ $200 \mathrm{~kg} / \mathrm{cm}^{3}$; detector: RID (reflective index detector).

\section{Enzymatic hydrolysis of the substrates with commercial enzymes}

The commercial enzymes Celluclast ${ }^{\circledR} 1.5 \mathrm{~L}$ and Cellubrix ${ }^{\circledR}$ L (Novozyme, Sweden) were used to compare the hydrolysis efficiency with the crude enzyme. Following the enzyme manufacturer's protocol, $50 \mu \mathrm{l}$ of each enzyme was mixed with $30 \mathrm{ml} 0.2 \mathrm{M}$ sodium acetate buffer $\mathrm{pH} 5$ containing $1 \%$ each of agricultural waste, and incubated at $30{ }^{\circ} \mathrm{C}$ for 48 hours. Samples were taken every 4 hours for protein and reducing sugar assay. Glucose and xylose content was determined by HPLC as described above.

Enzymatic hydrolysis of the substrates with the crude enzyme from $A$. aculeatus Iizuka FR60

The enzymatic hydrolysis of agricultural wastes was done by using the crude enzyme prepared as described above. The reaction mixture, containing $1 \%$ each of agricultural waste in $15 \mathrm{ml} 0.2 \mathrm{M}$ sodium acetate buffer $\mathrm{pH} 5$, and $15 \mathrm{ml}$ of the culture supernatant was incubated at $50{ }^{\circ} \mathrm{C}$ for 48 hours. 
Similar reaction mixture was prepared for the control (the supernatant of broth containing pretreated agricultural wastes). Samples were taken every 4 hours for protein and reducing sugar assay. Glucose and xylose content was determined by HPLC as described above.

\section{Protein and reducing sugar determination}

The amount of total protein was determined according to the Folin's Ciocalteau method described by Lowry et al. (15) using bovine serum albumin as a protein concentration standard. The concentration of reducing sugar during cultivation was measured by the dinitrosalicylic acid (DNS) method (20) using glucose and xylose solution as a standard reference.

The mean specific rate (MSR) was calculated to compare the effectiveness of tested enzymes in hydrolyzing pretreated agricultural wastes. It is the average of the rates of cellulose hydrolysis for 12 hours of incubation per mg of total loaded protein (g glucose $\mathrm{l}^{-1} \mathrm{mg}^{-1} \mathrm{hr}^{-1}$ ) (5). In this work, the specific rate was calculated to $\mu \mathrm{g}$ reducing sugar $\mathrm{g}^{-1}$ dry weight substrate $\mathrm{mg}^{-1}$ enzyme $\mathrm{hr}^{-1}$.

\section{RESULTS AND DISCUSSION}

\section{Screening of fungal isolates producing CMCase and} xylanase

Carboxymethyl cellulase (CMCase) and xylanase production by 42 fungal isolates from soil samples were examined. All of the isolates were capable of growing on the agar plates containing pretreated rice straw as the substrate. The isolate FR33 showed the highest CMCase activity of 572 $\mathrm{mU} / \mathrm{mg}$ total protein but no xylanase activity at all (Fig. 1). The highest xylanase activity was found from the isolate FR74 with $584 \mathrm{mU} / \mathrm{mg}$ protein and CMCase activity of $471 \mathrm{mU} / \mathrm{mg}$ protein (Fig. 1). Among all isolates, the isolate FR60 showed sufficient activity of both CMCase and xylanase of $517 \mathrm{mU} / \mathrm{mg}$ and $550 \mathrm{mU} / \mathrm{mg}$ proteins, respectively (Fig. 1). The isolate FR60 was selected for further characterization and hydrolysis of agricultural wastes.

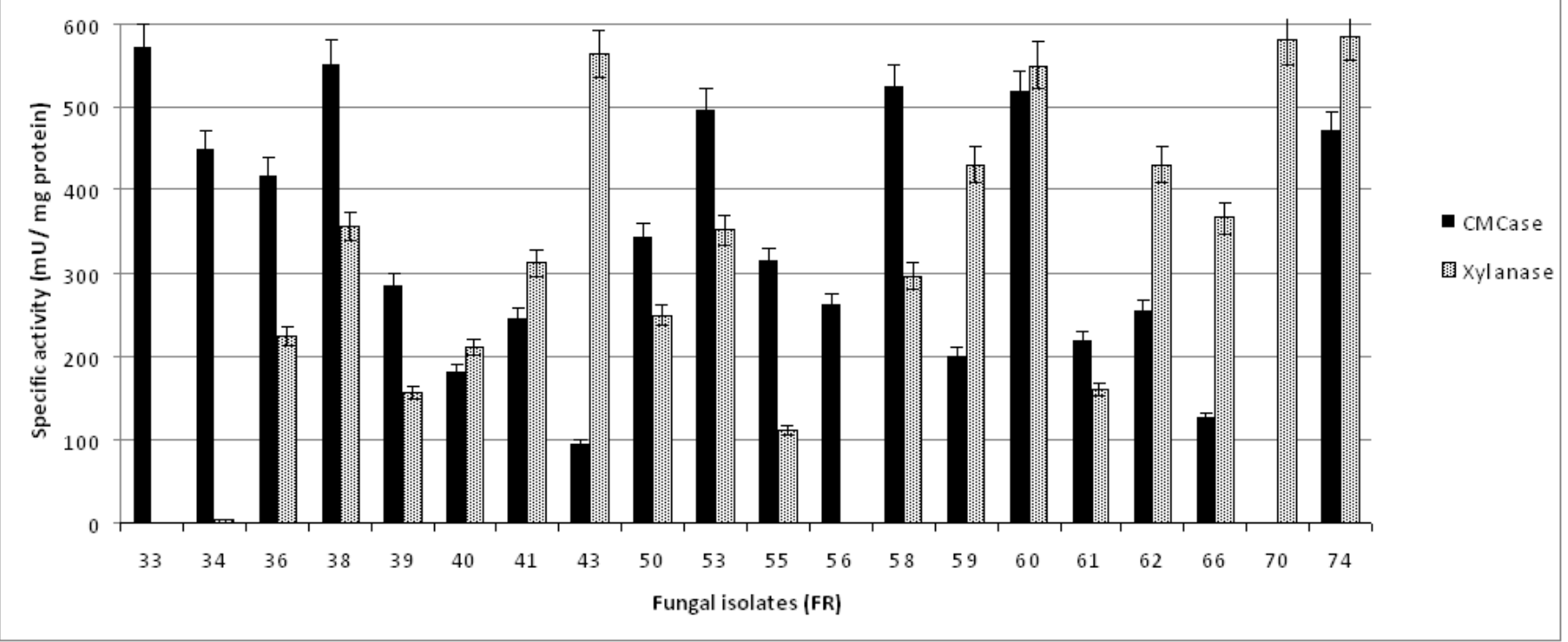

Figure 1. Carboxymethyl cellulase (CMCase) and xylanase specific activities of some fungal isolates from this study. 


\section{Morphological characteristics of the selected isolate}

Morphological characteristics of the fungal isolate FR60 was investigated and identified as described by Klich (12) and, Raper and Funnell (29). The colonies are brownish black, the conidiophores are smooth-walled with terminal, globule, 45-65 $\mu \mathrm{m}$ diameter vesicles. The sterigmata are arranged in one series. The conidiogenous cells (phialides) are flask-shaped (Fig. 2), 5-10 $\mu \mathrm{m}$ long and 3-4 $\mu \mathrm{m}$ wide. The conidia (spores) are subglobose to oval-shape (Fig. 2), 4-5 $\mu \mathrm{m}$ long and 3-4 $\mu \mathrm{m}$ wide, with an echinulate wall. Based on these results, the strain was identified as Aspergillus aculeatus Iizuka. Distinguished characteristics of $A$. aculeatus are black colony, one series of the sterigma, and oval shaped conidium. This species is not frequently encountered (12).

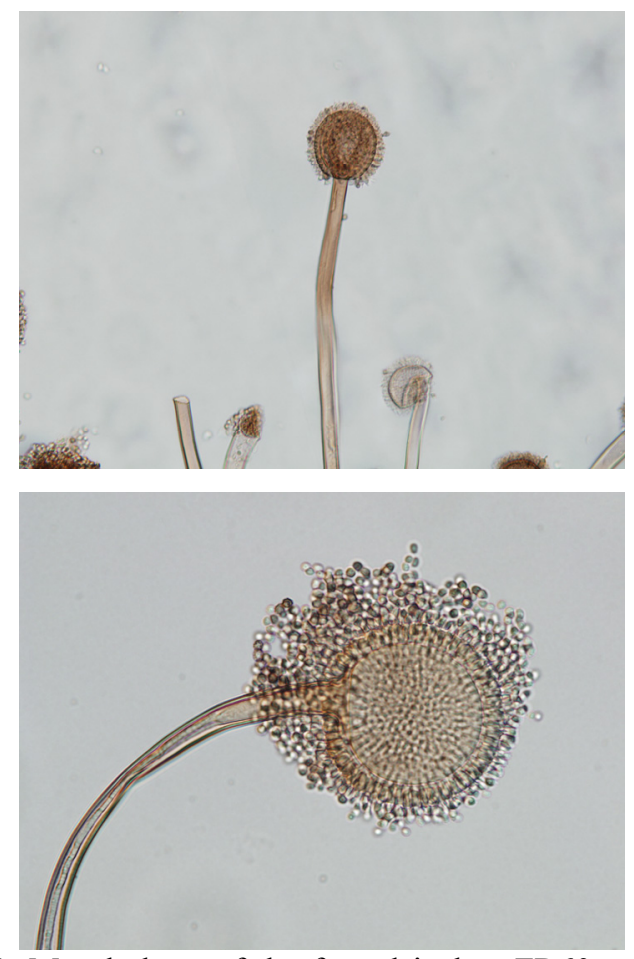

Figure 2. Morphology of the fungal isolate FR60, which was identified as Aspergillus aculeatus Iizuka.

A. aculeatus was shown to produce various kinds of cellulases (1). Later on, different kinds of cellulolytic enzymes were identified and studied from this fungus. A cellobiohydrolase I (cbhI) and a beta-glucosidase 1 (bgl1) gene of A. aculeatus were expressed in S. cerevisiae (33). A fulllength cDNA encoding a xyloglucan-specific endo -beta-1, 4glucanase (XEG) has been isolated from A. aculeatus as well (28). The enzyme hydrolyzes structurally diverse xyloglucans from various sources, but hydrolyzes no other cell wall component and can therefore be considered a xyloglucanspecific endo-beta-1, 4-glucanohydrolase (28). An endoglucanase from $A$. aculeatus was purified and showed a high specific activity toward carboxymethyl cellulose and low specific activity toward Avicel (22). A. aculeatus Iizuka FR60 isolated in this study was chosen for further study as a crude enzyme to hydrolyze various agricultural wastes compared with acid hydrolysis and hydrolysis by commercial enzymes.

\section{Chemical hydrolysis and enzymatic hydrolysis of various agricultural wastes}

The following agricultural wastes were tested: bagasse, corncob, peanut shell, rice hull, rice straw, stalk and leaf of sugar cane, and stalk and leaf of sweet sorghum. The composition of agricultural wastes tested in this study is given in Table 1. Bagasse and rice hull had the highest carbohydrate content. The high contents of cellulose, which were attributed to remaining starch and ash in the rice hull, are noteworthy. The most notable was the high-lignin content of peanut shell (Table 1). After treating the agricultural wastes with acid, as shown in Table 2, rice straw was found to release the most total sugar (59.5 g/100 g dry weight), whereas bagasse, rice hull, leaf and stalk of sugarcane and sweet sorghum showed approximately the same total sugar (43.8-49.6 g/100 g dry weight). Peanut shell released the least amount of total sugar yield (22.8 g/100 g dry weight). This corresponded to the least cellulose and hemicelluloses content (34.2\% of dry matter) in peanut shell among seven agricultural wastes shown in Table 1. This result showed a brief overview of total sugar in seven agricultural wastes under the defined experimental conditions. 
Table 1. Cellulose content and composition ( $\%(\mathrm{w} / \mathrm{w})$ of dry matter)

\begin{tabular}{lrrrr}
\hline Agricultural & Cellulose & Hemicelluloses & Lignin & Others \\
\hline Bagasse $^{\text {a) }}$ & 44 & 23 & 20 & 13 \\
Corncob $^{\text {b) }}$ & 34.1 & 42.5 & 12.8 & 10.6 \\
Peanut shell $^{\text {c) }}$ & 22.1 & 12.1 & 35.2 & 30.6 \\
Rice hull $^{\text {c) }}$ & 49.1 & 9.6 & 12.9 & 28.4 \\
Rice straw $^{\text {d) }}$ & 33 & 26 & 7 & 34 \\
Sugarcane leaf \& stalk $^{\text {d) }}$ & 40 & 29 & 13 & 18 \\
Sorghum leaf \& stalk $^{\text {d) }}$ & 31 & 30 & 11 & 28 \\
\hline a) Duenas et al.,1995; b) Singh and Kalra, 1978; c) Martin (tal. 2007; d) Marsden and Gray, 1986
\end{tabular}

a) Dueñas et al., 1995; b) Singh and Kalra, 1978; c) Martin et al., 2007; d) Marsden and Gray, 1986

Enzymes tested in this study could not hydrolyze rice hull efficiently ( $3 \%$ of total sugar comparing with total sugar yield from acid treatment) (Table 2). In contrast, they could effectively hydrolyze sugarcane leaf and stalk, and peanut shell (30-31\% total sugar comparing with total sugar yield from acid treatment). From the enzymatic treatment results, the lowest sugar yield was obtained from the rice hull treatment $(1.6$ $\mathrm{g} / 100 \mathrm{~g}$ dry weight) and the highest amount of reducing sugar came from the treatment of rice straw $(15.3 \mathrm{~g} / 100 \mathrm{~g}$ dry weight).

Table 2. Amount of total sugar (g/100 g dry weight) released from the tested agricultural products by acid and enzymatic treatments $(n=3)$. The last column shows an average percentage of the reducing sugars amount gained from the enzymatic reaction (Cellubrix ${ }^{\circledR} \mathrm{L}$, Celluclast ${ }^{\circledR} 1.5 \mathrm{~L}$, and the crude enzyme from A. aculeatus Iizuka FR60) comparing with the acid hydrolysis, by which the value was used as a complete $(100 \%)$ yield.

\begin{tabular}{lccccc}
\hline & Acid & Cellubrix $^{\circledR} \mathbf{L}$ & Celluclast $^{\circledR}$ 1.5L & $\begin{array}{c}\text { A.aculeatus } \\
\text { Iizuka FR60 }\end{array}$ & $\begin{array}{c}\text { Average } \\
\text { percentage }\end{array}$ \\
\hline Bagasse & $49.2 \pm 2.5$ & $7.8 \pm 0.4$ & $8.6 \pm 0.4$ & $7.4 \pm 0.4$ & $15 \%$ \\
Corncob & $38.4 \pm 1.9$ & $2.6 \pm 0.1$ & $8.0 \pm 0.4$ & $10.1 \pm 0.5$ & $24 \%$ \\
Peanut shell & $22.8 \pm 1.1$ & $6.8 \pm 0.3$ & $15.3 \pm 0.8$ & $6.7 \pm 0.3$ & $30 \%$ \\
Rice hull & $47.2 \pm 2.4$ & $1.6 \pm 0.1$ & $1.6 \pm 0.1$ & $3.3 \pm 0.2$ & $3 \%$ \\
Rice straw & $59.5 \pm 3.0$ & $24.9 \pm 1.2$ & $15.9 \pm 0.8$ & $14.7 \pm 0.7$ & $26 \%$ \\
Sugarcane leaf \& stalk & $43.8 \pm 2.2$ & $13.2 \pm 0.7$ & $13.9 \pm 0.7$ & $5.2 \pm 0.3$ & $31 \%$ \\
Sweet sorghum leaf \& stalk & $49.6 \pm 2.5$ & $10.8 \pm 0.5$ & $9.3 \pm 0.5$ & $9.3 \pm 0.5$ & $19 \%$ \\
\hline
\end{tabular}

Considering the acid hydrolysis as a complete hydrolysis in this study, rice hull, which showed a high sugar content from acid hydrolysis (47.2 g/100 g dry weight) could be poorly hydrolyzed by the enzymes (1.6 g/100 g dry weight). This could relate to biomass content in each agricultural residue since the pretreatment effectiveness is highly dependent on the chemical and physical properties of the feedstock (5). Rice hull is made of hard materials, including opaline silica and lignin, and has a recalcitrant cell wall structure (23). Therefore, the pretreatment would occur under a much harder condition than rice straw, which contains a lesser amount of lignin ( $7 \%$ of dry matter, Table 1). It is well documented that the adsorption of enzymes to both crystalline cellulose and lignin may significantly decrease the rate and the extent of cellulolytic degradation of cellulose in lignocellulosic substrates $(26,13)$. Other mechanisms, such as cellulases getting "stuck" within the cellulose, may slow down the enzymatic hydrolysis during the cellulolytic hydrolysis reactions as well (37). 


\section{Analysis of glucose and xylose content from chemical and enzymatic hydrolysis}

Substantial amounts of xylose and other reduced form of polysaccharides were found, whereas glucose was found in a relatively small amount among the sugar mixtures. Under the conditions used in this study, different enzymes could hydrolyze agricultural biomasses differently. This indicated the complexity of a solid material in each agricultural waste, which would allow for the access of particular enzyme to cellulose or hemicelluloses structure. The data provided us information how solid each agricultural waste was, and how much sugar is relatively present in the materials. Referring to the amount of total sugar from acid hydrolysis in Table 2, rice straw, sweet sorghum leaf and stalk, bagasse, rice hull, and sugarcane leaf and stalk could be potential sources of sugar. However, the highest amount of glucose was obtained from corncob by using the crude enzyme from $A$. aculeatus Iizuka FR60 $(10.1 \mathrm{~g} / 100 \mathrm{~g}$ dry substrate) (Table 3$)$.

Table 3. Yields of sugar from agricultural substrates after various hydrolysis stratagies (acid and enzymatic) (g/100 g dry substrate): $\mathrm{A}=$ Acid; $\mathrm{B}=$ Cellubrix ${ }^{\circledR} \mathrm{L} ; \mathrm{C}=$ Celluclast $^{\circledR} 1.5 \mathrm{~L} ; \mathrm{D}=$ the crude enzyme from A. aculeatus Iizuka FR60. $(\mathrm{n}=3$ )

\begin{tabular}{lcccccccccccc}
\hline & \multicolumn{4}{c}{ Glucose } & \multicolumn{4}{c}{ Xylose } & \multicolumn{4}{c}{ Other (reduced form) } \\
\hline & A & B & C & D & A & B & C & D & A & B & C & D \\
\hline Bagasse & 4.3 & 0 & 0 & 0 & 24.0 & 7.8 & 8.6 & 0 & 20.8 & 0 & 0 & 7.4 \\
Corncob & 4.7 & 0 & 0 & 10.1 & 28.1 & 0 & 8.0 & 0 & 5.6 & 2.6 & 0 & 0 \\
Peanut shell & 0 & 0 & 0 & 0 & 6.7 & 6.8 & 7.8 & 0 & 16.1 & 0 & 7.5 & 6.7 \\
Rice hull & 0 & 0 & 0 & 0 & 21.7 & 0 & 0 & 0 & 25.4 & 1.6 & 1.6 & 3.3 \\
Rice straw & 1.5 & 4.8 & 4.0 & 8.3 & 24.6 & 8.0 & 9.2 & 0 & 33.4 & 0 & 0 & 6.4 \\
Sugarcane leaf \& stalk & 2.1 & 0 & 0 & 0 & 27.4 & 8.0 & 9.0 & 0 & 14.3 & 5.2 & 4.9 & 5.1 \\
Sweet sorghum leaf \& stalk & 4.9 & 0 & 9.1 & 7.3 & 24.0 & 6.3 & 0 & 0 & 20.7 & 4.5 & 2 & 0 \\
\hline
\end{tabular}

Lee et al. (14) reported that the yield of total sugar from enzymatic hydrolysis of oxalic acid pretreated corncob was between 50 and $150 \mathrm{~g} / 100 \mathrm{~g}$ dry weight. Öhgren et al. (24) pretreated corn stover by using acid-catalyzed steam, and then used commercial enzyme mixture of Celluclast ${ }^{\circledR} 1.5 \mathrm{~L}$ and Novozyme 188 with and without Multifect ${ }^{\circledR}$ Xylanase to hydrolyze it for 72 hours. They obtained $15.5 \mathrm{~g}-28.5 \mathrm{~g}$ glucose/100 g dry weight. Cara et al. (6) converted olive tree biomass into fermentable sugar by a dilute-acid pretreatment and a enzymatic saccharification, and obtained $3.4 \mathrm{~g}-13.8 \mathrm{~g}$ glucose/100 g dry weight after enzymatic hydrolysis with Celluclast ${ }^{\circledR} 1.5 \mathrm{~L}$ and Novozyme 188 for 72 hours. The experiments mentioned above demonstrated that, due to different pretreatment strategies, various amount of total sugar could be different as well.

Xylose, derived from hemicelluloses was the major sugar found in all hydrolysates except in those treated with the crude enzyme from A. aculeatus Iizuka FR60 (Table 3). A. aculeatus Iizuka FR60 showed xylanase activity as shown in Fig. 1. However, the activity was determined by measuring reducing sugars, which could be mixtures of various heteropolymer sugar and not a xylose monomer. This suggested a presence of xylanases in the crude enzyme from A. aculeatus Iizuka FR60, but not a xylobiase. In another study, by which additional types of monomer sugar were analyzed (arabinose, galactose, mannose), the different sugar contents of the prehydrolysates indicates different composition of the hemicelluloses of the investigated materials (18). However, it is obvious that a yield of different sugar types is also a consequence of the different susceptibility to dilute-acid prehydrolysis displayed by different materials (18).

No glucose monomer was found by the enzymatic 
hydrolysis of rice hull, peanut shell, sugarcane leaf and stalk, as well as bagasse (Table 3). This might be related to the structure, and the lignin or the hemicelluloses content since xylan degradation in the pretreatment is important for degradation of cellulose during the enzymatic hydrolysis $(4,5)$. Within the plant cell wall architecture, hemicelluloses coat the cellulose-fibrils and result in a reduced accessibility of the cellulose-fibrils (19). Therefore, the enzymatic hydrolysis of the hemicelluloses is essential to facilitate complete cellulose degradation (34). It was reported that when hemicellulose was removed, cellulase saccharification was maximal even though the lignin contents were high (14).

Rice straw was the most susceptible material to the hydrolysis conditions used in this work since it is the only biomass that could be hydrolyzed to glucose in all treatments. The low glucose content in hydrolysates treated with acid could be a result of the degradation of monosaccharide since furan aldehydes and other forms of furfurals were products of acid-catalyzed degradation (18). Martin et al. (18) also reported that the concentration of furan aldehydes increased with increasing pretreatment time. The condition used in that study was 60 minutes at $122{ }^{\circ} \mathrm{C}$, while this work used a much harsher condtition $\left(120^{\circ} \mathrm{C}\right.$ for 3 hours and subsequently $140{ }^{\circ} \mathrm{C}$ for 3 hours). However, in order to hydrolyze lignocellulosic materials effectively, mixtures of enzymes are required, as shown by the previous studies using mixtures of endoglucanases (e.g. Celluclast $\left.{ }^{\circledR} 1.5 \mathrm{~L}\right)$ together with Cellobiase (e.g. Novozyme 188) and/or, depending on type of lignocellulosic materials, additional xylanase (e.g. Multifect ${ }^{\circledR}$ ) $(4,5,6,24)$. Furthermore, pretreatment strategies of the materials are very important key factors as well $(4,5,14,24)$.

\section{Comparison the hydrolysis ability of the crude enzyme} from $A$. aculeatus Iizuka FR60 with commercial enzymes on various agricultural wastes

The effectiveness of the tested enzymes in hydrolysis of pretreated agricultural wastes was evaluated by using the mean specific rate (4). Berlin et al. (4) reported a yield of glucose between 800 and $5,000 \mu \mathrm{g} \mathrm{g}^{-1}$ dry weight substrate $\mathrm{mg}^{-1}$ enzyme $\mathrm{hr}^{-1}$ after incubations of softwood samples with commercial and laboratory cellulase preparations with exogenous $\beta$-glucosidase supplementation after pretreated by steam explosion or organosolv pretreatment (4). In this study, the hydrolysis rate of rice straw by Cellubrix ${ }^{\circledR} \mathrm{L}$ was $270 \mu \mathrm{g}$ sugar $\mathrm{g}^{-1}$ dry weight substrate $\mathrm{mg}^{-1}$ enzyme hr${ }^{-1}$ (Fig. 3), which was the highest rate under the defined conditions. Cellubrix ${ }^{\circledR} \mathrm{L}$ could also hydrolyze bagasse at a higher rate than other enzymes in this experiment.

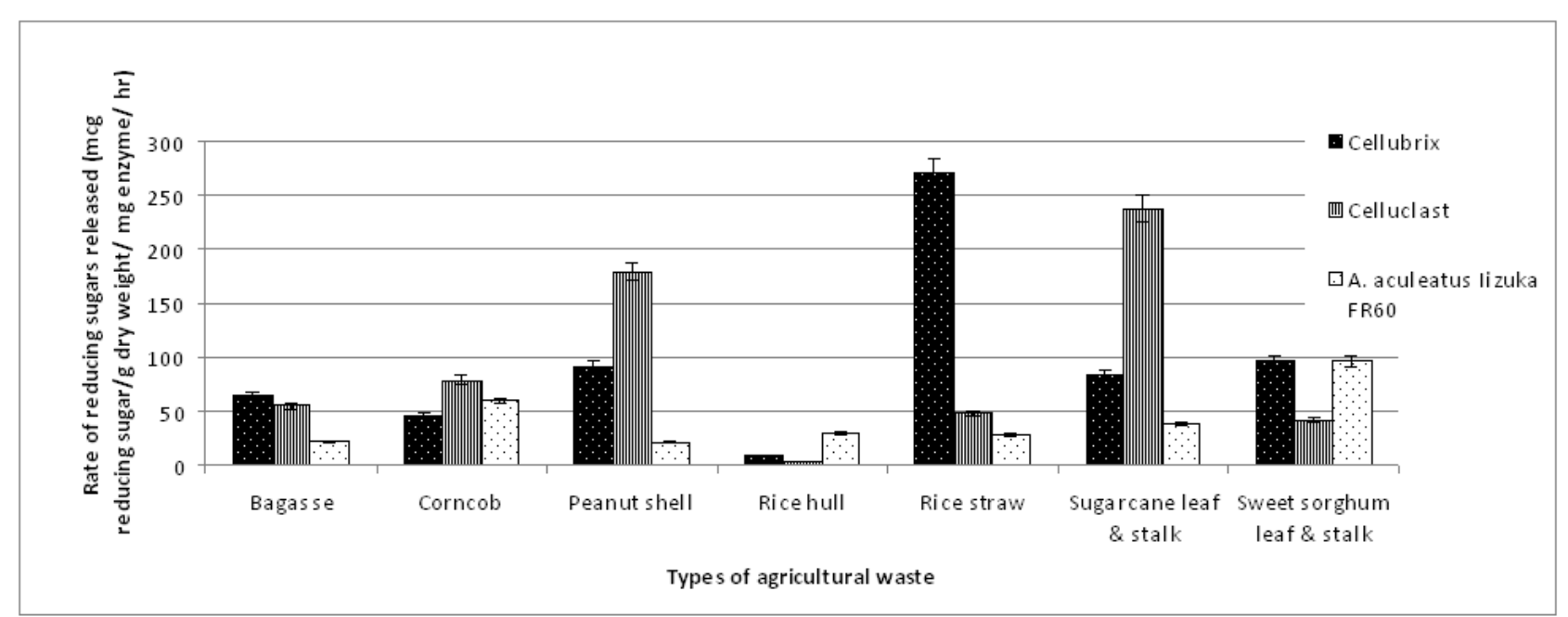

Figure 3. The mean specific rate of the enzymatic hydrolysis. Reducing sugars released in the hydrolysates were analyzed with the DNS $\operatorname{method}(\mathrm{n}=3)$. 
The highest rate for glucose release was from the hydrolysis of corncob, and sweet sorghum leaf and stalk with the crude enzyme from $A$. aculeatus Iizuka FR60 (95 $\mu \mathrm{g}$ glucose $\mathrm{g}^{-1}$ dry weight substrate $\mathrm{mg}^{-1}$ enzyme $\mathrm{hr}^{-1}$ ) (data not shown). Cellubrix ${ }^{\circledR} \mathrm{L}$ and the crude enzyme from $A$. aculeatus Iizuka FR60 could hydrolyze sweet sorghum leaf and stalk at almost the same rate. Furthermore, A. aculeatus Iizuka FR60 showed a comparable ability to the commercial enzymes in hydrolyzing corncob, and sweet sorghum leaf and stalk (Fig. $3)$.

From all agricultural wastes tested in this work, rice hull was the hardest substrate to be hydrolyzed by the enzymes (Fig. 3), which was also observed by Martin et al. (18). They discussed that the enzymatic convertibility of pretreated rice hull was unexpectedly lower than that of the unpretreated materials. Thus indicated either that the pretreatment used for the material was inadequate or that easily hydrolysable glucans were present. Rice hull contained noncellulose glucans that were not characterized, and perhaps, those glucans could be hydrolyzed by the enzyme preparation used without pretreatment. More severe conditions of the dilute sulfuric acid prehydrolysis of rice hull were suggested to be essential for improving the subsequent enzymatic hydrolysis of cellulose (18).

Interestingly, the crude enzyme from $A$. aculeatus Iizuka FR60 showed a higher rate in the rice hull hydrolysis than the two other commercial enzymes $\left(29 \mu \mathrm{g}\right.$ sugar $\mathrm{g}^{-1}$ dry weight substrate $\mathrm{mg}^{-1}$ enzyme $\mathrm{hr}^{-1}$ ) (Fig. 3). Since A. aculeatus Iizuka possessed highly active pectolytic enzyme (pectinase), which was commercialized by Novozyme (Pectinex ${ }^{\circledR}$ Ultra SPL, Novozyme Corp.), it is suggested that the crude enzyme from $A$. aculeatus Iizuka FR60 could penetrate the robust structure of rice hull better than Cellubrix ${ }^{\circledR} \mathrm{L}$ or Celluclast ${ }^{\circledR} 1.5 \mathrm{~L}$. BenShalom (3) also observed that extraction of pectin with $\mathrm{NaOH}$ and EDTA prior to treatment with cellulase resulted in more glucose production than treatment with cellulase alone. This indicates that pectin hinders the hydrolysis of cellulose and hemicelluloses in the rice hull cell wall, and must be hydrolyzed or extracted for cellulases and hemicellulases in order to effectively degrade other cell wall polysaccharides. The cell wall model for Xowering plants proposed by Carpita and Gibeaut (7), which stated that a pectin matrix surrounds cellulose fibers coated with xyloglucan, a hemicellulose, supports the hypothesis of a steric hindrance of cellulose and hemicellulose hydrolysis by pectin.

In conclusion, A. aculeatus Iizuka FR60 showed its overall usefulness in hydrolyzing various agricultural wastes, by which its efficiency was comparable to the tested commercial enzymes. This result showed the potential use of enzymes from $A$. aculeatus Iizuka in hydrolyzing specific kinds of agricultural wastes such as rice hull, and therefore, as an alternative to commercial enzymes from Trichoderma reesei.

\section{CONCLUSION}

From this study, the fungal isolate FR60, which showed high CMCase and xylanase activities when compared with other isolates of same origin, was identified as Aspergillus aculeatus Izuka. Under the tested condition, the crude enzyme from A. aculeatus Iizuka FR60 could hydrolyze some agricultural residues such as corncob, and sweet sorghum leaf and stalk at almost the same rate as that from the commercial enzymes. From all agricultural wastes tested in this work, rice straw was effortlessly hydrolyzed by both acid and enzyme treatment, whereas rice hull was the most difficult one to be hydrolyzed by enzymes. However, the crude enzyme from $A$. aculeatus Iizuka FR60 showed higher rate in hydrolysis of rice hull than the two other commercial enzymes. This study showed a potential use of enzymes from A. aculeatus Iizuka to hydrolyze specific kinds of agricultural wastes such as rice hull, and therefore as an alternative to commercial enzymes from $T$. reesei. 


\section{ACKNOWLEDGEMENTS}

This work was partly supported by the Higher Education Research Promotion and National Research University Project of Thailand, Office of the Higher Education Commission, through the Biofuel Cluster of Khon Kaen University, the Young Researcher Grant, Khon Kaen University and the Protein and Proteomics Research Group (PPRG), Faculty of Science, Khon Kaen University. The author would like to thank Mr. Ritthirong Saelee, Miss Siraprapa Saraihom, Miss Supada Fangkam and Mr. Watit Suk-em for technical supports.

\section{REFERENCES}

1. Adisa, V.A.; Fajola, A.O. (1983). Cellulolytic enzymes associated with the fruit rots of Citrus sinensis caused by Aspergillus aculeatus and Botryodiplodia theobromae. Z. Allg. Mikrobiol. 23 (5), 283-8.

2. Anonymouse (2009). Thailand Alternative Energy Situation 2009. Alternative Energy and Efficiency Information Center, Department of Alternative Energy Development and Efficiency, Ministry of Energy, Royal Thai Government.

3. Ben-Shalom, N. (1986). Hindrance of hemicellulose and cellulose hydrolysis by pectic substances. J. Food Sci. 51, 720-721, 730.

4. Berlin, A.; Gilkes, N.; Kilburn, D.; Bura, R.; Markov, A.; Skomarovsky, A.; Okunev, O.; Gusakov, A.; Maximenko, V.; Gregg, D.; Sinitsyn, A.; Saddler, J. (2005). Evaluation of novel fungal cellulase preparations for ability to hydrolyze softwood substrates - evidence for the role of accessory enzymes. Enzyme. Microb. Technol. 37, 175-184.

5. Berlin A.; Gilkes, N.; Kilburn, D.; Maximenko, V.; Bura, R.; Markov, A.; Skomarovsky, A.; Gusakov, A.; Sinitsyn, A.; Okunev, O.; Solovieva, J.; Saddler, J.N. (2006). Evaluation of cellulase preparations for hydrolysis of hardwood substrates. Appl. Biochem. Biotechnol. 129-132, $528-545$.

6. Cara, C.; Ruiz, E.; Oliva, J.M.; Sáez, F.; Castro, E. (2008). Conversion of olive tree biomass into fermentable sugars by dilute acid pretreatment and enzymatic saccharification. Bioresour. Technol. 99, 1869-1876.

7. Carpita, N.C.; Gibeaut, D.M. (1993). Structural models of primary cell walls in Xowering plants : consistency of molecular structure with the physical properties of the walls during growth. Plant J. 3, 1-30.

8. Chandel, A.K.; Chan, E.S.; Rudravaram, R.; Narasu, M.L.; Rao, L.V.; Ravindra, P. (2007). Economics and environmental impact of bioethanol production technologies : an appraisal. Biotechnol. Mol. Biol. Rev. 2 (1), 14-32.
9. Dueñas, R.; Tengerdy, R.P.; Gutierrez-Correa, M. (1995). Cellulase production by mixed fungi in solid-substrate fermentation of bagasse. World J. Microbiol. Biotechnol. 11, 333-337.

10. Galbe, M.; Zacchi, G. (2002). A review of the production of ethanol from softwood. Appl. Microbiol. Biotechnol. 59, 618-628.

11. Hamelinck, C.N.; van Hooijdonk, G.; Faaij, A.P.C. (2005). Ethanol from lignocellulosic biomass: techno-economic performance in short-, middle-, and long-term. Biomass Bioenergy 22, 384-410.

12. Klich, M.A. (2002). Identification of common Aspergillus species. CBS, the Netherlands.

13. Laureano-Perez, L.; Teymouri, F.; Alizadeh, H.; Dale, B.E. (2005). Understanding Factors that Limit Enzymatic Hydrolysis of Biomass : Characterization of pretreated Corn Stover. Appl. Biochem. Biotechnol. 121-124, 1081-1099.

14. Lee, J.W.; Rodrigues. R.C.L.B.; Kim, H.J.; Choi, I.; Jeffries, T.W. (2010). The roles of xylan and lignin in oxalic acid pretreated corncob during separate enzymatic hydrolysis and ethanol fermentation. Bioresour. Technol. 101, 4379-4385.

15. Lowry, O.H.; Rosebrough, N.J.; Farr, A.L.; Randall, R.J. (1951). Protein Measurement with the Folin Phenol Reagent. J. Biol. Chem. 193, 265.

16. Lyons, T.R. (2004). Ethanol around the world: rapid growth in policies, technology and production. In: Jacques, K.A., Lyons, T.P., Kelsall, D.R.(eds). The Alcohol Textbook (fourth ed.), Nottingham University Press, Nottingham, UK, p.1-8.

17. Marsden, L.M.; Gray, P.P. (1986). Enzymatic hydrolysis of cellulose in lignocellulosic material. Crit. Rev. Biotechnol. 3 (3), 235-265.

18. Martin, C.; Alriksson, B.; Sjöde, A.; Nilvebrant, N.O.; Jönsson, L.J. (2007). Dilute sulfuric acid pretreatment of agricultural and agroindustrial residues for ethanol production. Appl. Biochem. Biotechnol. 136-140, 339-352.

19. McCann, M.C.; Roberts, K. (1991). Architecture of the primary cell wall. In: Lloyd, E.D.(ed). The cytoskeletal basis of plant growth and form. Academic Press, New York, USA, p.109-129.

20. Miller, G.L. (1959). Use of dinitrosalicylic acid reagent for determination of reducing sugar. Anal. Chem. 31, 426-428.

21. Miller, G.L.; Blum, R.; Glennon, W.E.; Burton, A.L. (1960). Measurement of carboxymethylcellulase activity. Anal. Chem. 1 (2), 127-132.

22. Naika, G.S.; Kaul, P.; Prakash, V. (2007). Purification and characterization of a new endoglucanase from Aspergillus aculeatus. J. Agric. Food Chem. 55 (18), 7566-7572.

23. Namiki, M.; Ma, J.F.; Iwashita, T. (2005). Identification of the silicon form in xylem sap of rice (Oryza sativa L.) Plant Cell Physiol. 46 (2), 279-283.

24. Öhgren, K.; Bura, R.; Saddler, J.; Zacchi, J. (2007). Effect of hemicellulose and lignin removal on enzymatic hydrolysis of steam 
pretreated corn stover. Bioresour. Technol. 98, 2503-2510.

25. Palmqvist, E.; Hahn-Hägerdal, B. (2000). Fermentation of lignocellulosic hydrolyzates II : inhibitors and mechanisms of inhibition. Bioresour. Technol. 74, 25-33.

26. Palonen, H.; Tjerneld, F.; Zacchi, G.; Tenkanen, M. (2004). Adsorption of purified Trichoderma reesei cellulases and their catalytic domains to steam pretreated softwood and isolated lignin. J. Biotechnol. 107, 65-72.

27. Parajó, J.C.; Domínguez, H.; Domínguez, J.M. (1998b). Biotechnological production of xylitol. Part 3 : operation in culture media made from lignocellulosic hydrolysates. Bioresour. Technol. 66, $25-40$.

28. Pauly, M.; Andersen, L.N.; Kauppinen, S.; Kofod, L.V.; York, W.S.; Albersheim, P.; Darvill, A. (1999). A xyloglucan-specific endo-beta-1, 4glucanase from Aspergillus aculeatus : expression cloning in yeast, purification and characterization of the recombinant enzyme. Glycobiology. 9 (1), 93-100.

29. Raper, K.B.; Funnell, D.I. (1965). The genus Aspergillus. The Williams \& Wilkins Company, Baltimore, USA.

30. Rosgaard, L.; Pedersen, S.; Meyer, A.S. (2007). Comparison of different pretreatment strategies for enzymatic hydrolysis of wheat and barley straw. Appl. Biochem. Biotechnol. 143, 284-296.
31. Singh, A.; Kalra, M.S. (1978). Single cell protein production from corn cobs. J. Food Sci. Technol. 15, 249-252.

32. Sun, Y.; Cheng, J. (2002). Hydrolysis of lignocellulosic materials for ethanol production : a review. Bioresour. Technol. 83, 1-11.

33. Takada, G.; Kawaguchi, T.; Sumitani, J.; Arai, M. (1998). Expression of Aspergillus aculeatus No. F-50 cellobiohydrolase I (cbhI) and betaglucosidase 1 (bgl1) genes by Saccharomyces cerevisiae. Biosci. Biotechnol. Biochem. 62 (8), 1615-1618.

34. Vincken, J.P.; Beldman, G.; Voragen, A.G.J. (1994). The effect of xyloglucans on the degradation of cell wall embedded cellulose by the combined action of cellobiohydrolase and endoglucanases from Trichoderma viride. Plant Physiol. 104, 99-107.

35. Vincken, J.P.; De Keizer, A.; Beldman, G.; Voragen, A.G.J. (1995). Fractionation of xyloglucan fragments and their interaction with cellulose. Plant Physiol. 108, 1579-1585.

36. Wilkins, M.R.; Widmer, W.W.; Grohmann, K.; Cameron, R.G. (2007). Hydrolysis of grapefruit peel waste with cellulase and pectinase enzymes. Bioresour. Technol. 98, 1596-1601.

37. Yang, B.; Willies, D.M.; Wyman, C.E. (2006). Changes in the enzymatic hydrolysis rate of avicel cellulose with conversion. Biotechnol. Bioeng. $94(6), 1122-1128$ 